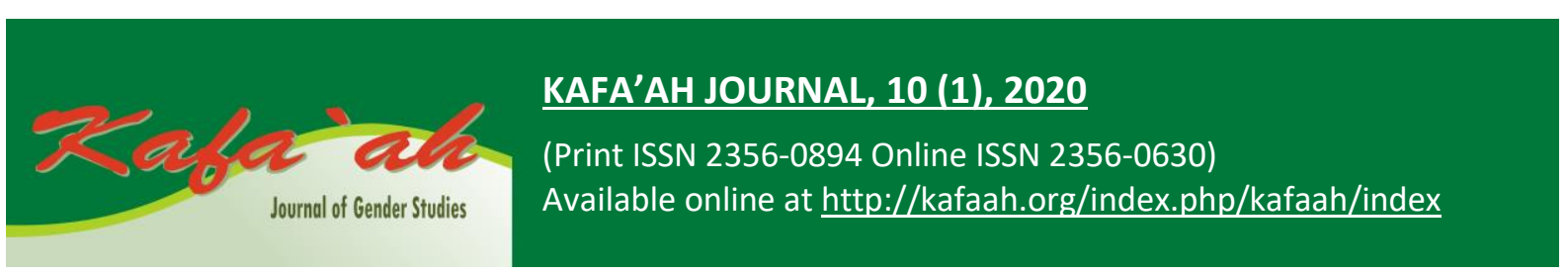

\title{
OTORITAS KEAGAMAAN PEREMPUAN (Studi atas Fatwa-Fatwa Perempuan di Pesantren Kauman Jekulo Kudus)
}

\author{
Moh. Muhtador \\ Institut Agama Islam Negeri Kudus, Indonesia \\ E-mail: muhtador@iainkudus.ac.id
}

\begin{abstract}
This paper examines about religious authority of women in the Islamic Boarding School Kauman Jekulo Kudus. The problem of female ontology which is described as God's creation from men's ribs has a negative impact on women's lives in both the private and social spheres. The problem does not have much effect on the position of women who have scientific and high social status, such as nyai, ustazah and lecturers. Doubts about women's competence coincided with religious dogmas that explicitly refer to women as being under estimate, raising doubts about women's credibility. This study is a qualitative approach with data collection techniques through observation or documentation and interviews with several community leaders, women activists and communities around the pesantren in Kauman, Kudus, Central Java and the data obtained were analyzed descriptively. The results showed that the authority of the fatwa issued by women was only binding on one's own family and did not affect to other communities. Women's religious fatwa (nyai) only binds female students and women around the village. Meanwhile, in general religious authority was still controlled by men. Thus, women did not have a significant role in the pesantren environment and the general public, because the community and santri trusted the religious fatwa issued by men, even though it was from the Islamic cleric with credibility under it. This phenomenon became interesting because dogmatically Islam did not distinguish between sexes in delivering religious fatwas. However, the public believed more in men's fatwas in conveying their religious authority.
\end{abstract}

Keywords: Religious Fatwa, Women's Authority, Society and Islamic Boarding School

\begin{abstract}
Abstrak
Tulisan ini mengkaji tentang otoritas keagamaan perempuan di lingkungan Pesantren Kauman Jekulo Kudus. Masalah ontologi perempuan yang digambarkan sebagai ciptaan Tuhan dari tulang rusuk laki-laki berdampak negatif bagi kehidupan perempuan baik di wilayah privat maupun sosial dan masalah tersebut tidak banyak berpengaruh pada posisi perempuan yang memiliki keilmuan dan status sosial tinggi, seperti nyai, ustazah dan dosen. Keraguan akan kompetensi perempuan bersamaan dengan dogma agama yang menyebut perempuan secara eksplisit makhluk nomor dua, sehingga memunculkan keraguan tentang kredebilitias perempuan. Kajian ini merupakan penelitian lapangan yang bersifat kualitatif dengan teknik pengumpulan data melalui observasi atau dokumentasi dan wawancara dengan beberapa tokoh masyarakat, aktivis perempuan dan masyarakat di sekitar pesantren di Kauman, Kudus, Jawa Tengah dan data yang diperoleh dianalisis secara deskriptif. Adapun hasil dari penelitian menggambarkan bahwa otoritas fatwa yang dikeluarkan perempuan hanya mengikat bagi keluarga sendiri dan tidak berpengaruh pada masyarakat lain. Fatwa keagamaan perempuan (nyai) hanya mengikat santri putri dan kaum ibu-ibu di sekitar kampung. Sementara itu, secara umum otoritas keagamaan masih dikendalikan oleh kaum laki-laki. Dengan demikian, perempuan tidak mempunyai peran signifikan dalam lingkungan pesantren maupun masyarakat umum, karena masyarakat dan santri lebih mempercayai fatwa keagamaan yang dikeluarkan oleh kaum laki-laki, meskipun itu dari ustaz dengan kredibilitas di bawah nyai. Fenomena ini jadi menarik karena secara dogmatis Islam tidak membedakan jenis kelamin dalam menyampaikan fatwa keagamaan. Namun, masyarakat lebih meyakini fatwa-fatwa laki-laki dalam menyampaikan otoritas keagamaannya.
\end{abstract}

Kata Kunci: Fatwa Keagamaan, Otoritas Perempuan, Masyarakat dan Pesantren 


\section{PENDAHULUAN}

Perempuan selalu menarik untuk diperbincangkan, mulai dari wilayah privat sampai ruang sosial. Pada wilayah privat, perempuan digambarkan sebagai makhluk yang taat karena eksistensi dan perilaku kesehariannya ditentukan oleh orang lain, seperti bapak, suami dan keluarga lainnya. Begitu juga pada wilayah sosial, perempuan dianggap sebagai makhluk yang membawa bencana, karena perilaku perempuan diatur dengan kesepakatan kaum lakilaki, seperti harus menjaga penampilan. Secara umum, tafsir tentang perempuan dalam dunia privat dan sosial ditentukan oleh kesepakatan budaya dan dogma agama (Muhtador, 2017).

Hegemoni budaya dan agama dalam mendeskripsikan perempuan sebagai makhluk lemah juga berkembang di wilayah pesantren. Hal ini dapat dibuktikan dengan beberapa bahan kajian yang diajarkan, seperti kitab 'Uqud al-Lujain, Tafsir Jalalain, Tijanu al Darari dan beberapa kitab fiqh serta kitab akhlaq (Ratnasari, 2016). Salah satu alasan atau faktor yang menyebabkan munculnya paham diskriminasi perempuan ialah adanya anggapan secara teologi bahwa perempuan tercipta dari tulang rusuk laki-laki dan anggapan tersebut telah menyebar di kalangan masyarakat serta diyakini sebagai ajaran agama yang harus dipatuhi. Menurut Nasaruddin yang dikutip Muhtador (2015) bahwa ketika mitologi dituangkan dalam bahasa agama pengaruhnya akan bertambah kuat. Hal tersebut disebabkan oleh keyakinan bahwa kitab suci bukanlah sekedar mitologi, tetapi bersumber dari Tuhan. Bahkan berbagai mitologi telah terintegrasi dalam tradisi keagamaan dan termanifestasikan dalam berbagai bentuk kepercayaan.

Beberapa penelitian yang berhubungan dengan isu perempuan dan pesantren telah banyak dilakukan oleh peneliti sebelumnya. Salah satu tulisan yang menarik tentang gender dan pesantren yaitu kajian Marhumah (2012) dengan menggunakan teori diskursus Foucault yang mengedepankan kuasa dan pengetahuan, meskipun wacana tentang gender mulai masuk dalam wilayah pesantren, tetapi harus diakui hegemoni/kuasa masih merujuk pada kyai dan ustad. Kuatnya hegemoni laki-laki atau agen agama tidak hanya dalam lungkup pesantren, termasuk dalam wilayah sosial-kemasyarakatan. Hegemoni tersebut muncul dari otoritas kyai atau ustad yang dianggap menguasai ilmu agama dan diyakini sebagai pewaris Nabi karena bagian dari representasi Ulama. Kontek ini memunculkan makna tunggu dalam menguatkan posisi laki-laki (Vita, 2014, p. 134)

Meski demikian, kajian terkait perempuan dan gender tidak hanya mengangkat isu-isu tentang diskriminasi perempuan, karena wacana tentang keadilan, kesetaraan antara laki-laki dan perempuan dalam konteks privat dan publik harus disuarakan lebih keras. Hal ini bertujuan untuk mengukur atau melihat sejauh mana perempuan mempunyai peran dan berkontribus dalam kehidupan, seperti kajian tentang makna penciptaan perempuan yang lebih egaliter yang diwacanakan Amina Wadud (1994) atau karya Fatima Mernisi (1991) yang mengkiritik sejarah atas perkembangan ajaran agama yang bias gender serta karya Riffat Hasan (1995) yang mengkritisi budaya atas logika patriarki dalam masyarakat Islam India.

Adapun dalam bentuk literatur jurnal ilmiah, dapat ditemukan cukup banyak wacana terkait kontribusi perempuan dalam kancah politik sosial, seperti tulisan Umma Farida (2018) yang mengungkap peran dan perjuangan perempuan dalam mempromosikan gerakan transformasi sosial, dimana peran tersebut merasa terpinggirkan dan bahkan dilupakan. Meskipun sejarah mencatat bahwa perempuan terlibat dalam mempromosikan transformasi sosial, seperti kemanusiaan dan kebangsaan. Farida Ulyani (2014) di mana perempuan dapat berperan adanya gerakan seperti muslimah center yang digagas oleh Pondok Pesantren Darut Tauhid. Hal ini merupakan kesadaran perempuan dalam menggali potensi perempuan sehingga dapat memperkuat sistem perekonomian keluarga. Begitu juga kajian Ambarwati dan Aida Husan (2014) tentang kepemimpinan nyai di Pati atas pesantren responsif gender yaitu nyai tidak lagi dipandang sebagai individu yang ekslusif tetapi dengan intelektual, spiritual dan kemampuan manajemen yang dikuasai ibu nyai dapat menjadi manifestasi kyai 
dalam berpartisipasi mengembangkan lembaga. Dengan demikian, akan tercipta sistem dan lingkungan yang elegan dengan cara segregasi gender yang dapat memberikan kesempatan pada laki-laki dan perempuan secara bersamaan (Muafiah, 2013)

Tiga tipologi pola pada kajian sebelumnya meliputi hegemoni patriaki, kritik dan kontribusi perempuan, sehingga perlu dipertanyakan beberapa hal tentang otoritas perempuan di hadapan masyarakat pesantren dan sekitarnya, yaitu bagaimana hubungan budaya dan agama dalam mengkonstruksi perempuan. Pada wilayah yang sama juga akan ditanyakan otoritas keagamaan apa saja yang dapat dimainkan oleh kalangan perempuan di pesantren.

Artikel yang sedang dikaji mempunyai tujuan untuk mengkaji peran perempuan yang lebih memfokuskan pada otoritas perempuan dalam perannya di publik dalam memberikan fatwa kegamaan di lingkungan pesantren di Kauman Jekulo Kudus. Hal ini tidak terbatas pada para istri kyai (ibu nyai), tetapi meliputi keseluruhan elemen bagi kaum perempuan-apakah aktivis perempuan, tokoh perempuan, dan lainnya dalam memberikan kontribusi keagamaannya di kalangan masyarakat setempat. Kajian ini menarik, karena secara geografis Kauman Jekulo berada di wilayah Timur dari Kabupaten Kudus, dan wilayah yang memiliki banyak pesantren dan madrasah pendidikan agama (Aviv, 2015). Selain itu, Kauman Jekulo dikenal sebagai wilayah yang sangat religius dan masih memegang teguh kepercayaan lama, seperti perempuan tidak boleh ziarah kubur, shalat di masjid dan memimpin kegiatan kegamaan yang bersifat umum. Oleh sebab itu, kondisi perempuan secara umum digambarkan sebagai makhluk yang patuh dan taat. Namun hal tersebut bukan berarti menghilangkan eksistensi perempuan di wilayah sosial, karena ada beberapa gejala hidupnya peran keagamaan yang dimainkan oleh kelompok perempuan.

\section{METODE PENELITIAN}

Jenis artikel ini adalah lapangan (field research) di mana penulis menjadi instrumen dalam melakukan penelitian untuk mengungkap, memahami dan menafsirkan femomena terkait perempeuan di sekitar pesantren (Ulya, 2010). Adapun pendekatan yang digunakan ialah kualitatif untuk memperoleh data yang mendalam berdasarkan pemahaman-pemahaman para informan, sedangkan data didapatkan dari hasil wawancara, observasi ataupun dokumentasi dengan dengan tokoh masyarakat (ibu nyai), aktivitis perempuan (istri RT, RW, dan kepala desa) serta ibu-ibu di sekitar pesantren dalam kisaran umurnya 46 sampai 60 tahun dan analisis data dilakukan untuk mengelompokkan informasi berdasarkan strata sosial dan mengkategorisasikan bentuk data serta menguraikan dengan rinci secara deskriptif (Moleong, 2002)

\section{HASIL DAN PEMBAHASAN}

\section{Pesantren dan Otoritas Keagamaan}

Pesantren adalah lembaga tertua yang hadir sebelum Indonesia memperoleh kemerdekaan. Eksistensi pesantren mempunyai peran penting dalam menjaga kedaulatan bangsa, yaitu sebagai identitas keagamaan masyarakat, karena di pesantren setiap orang diajarkan tentang ilmu-ilmu agama dan menjadi tempat pembinaan bagi calon-calon guru agama, kyai dan ulama. Begitu juga pesantren menjadi benteng perlawan dan pertahanan bagi umat Islam dalam menjaga dan mengawal negara dalam menentang praktik yang dilakukan oleh para penjajah atas rakyat Indonesia (Kusdiana, 2014).

Kata pesantren di daerah Jawa dan Madura sebelum tahun 60-an dikenal dengan sebutan pondok, yaitu kata yang menunjukkan pada tempat tinggal santri yang disyinalir diambil dari Bahasa Arab "funduq" yang mempunyai makna hotel atau asrama (Setiawan, 2012). Adapun definisi pesantren menurut Hasbullah (Hasbullah, 1999) ialah satu wilayah yang terdapat tempat tinggal untuk kyai dan santri dalam satu komplek. Secara kultural pesantren 
merupakan budaya asli masyarakat pribumi yang berhubungan dengan pendidikan agama, dan pesantren muncul secara natural karenaya adanya kesadaran akan pentingnya pendidikan agama dalam kehidupan (Hajar, 2009). Beberapa gagasan terkait pesantren pada dasarnya menemukan titik sama yaitu menarasikan pesantren sebagai pusat peradaban Islam yang lahir di luar wilayah Arab sebagai media bagi muslim Indonesia untuk membekali dan mempersiapkan diri sebagai generasi kyai, ulama dan kader Islam.

Peran pesantren dalam membentuk dan menyiapkan generasi Islam tidak lepas dari seorang kyai. Dalam perspektif sosiologis, kyai menjadi tokoh penting dalam struktur pesantren, karena dapat mempertemukan dan mempersatukan para santri dari pelbagai ras, suku dan daerah. Kemudian masing-masing santri dapat berinteraksi dan bersosialisasi dalam satu tempat. Tanggung jawab pesantren berada di bawah pengawasan seorang kyai, meskipun pada realitasnya dibantu oleh pengurus (santri senior) yang bertugas membantu menjalankannya. Peran kyai tidak hanya terbatas pada internal pesantren tetapi juga mempunyai akses yang sangat luas, yaitu sampai ke masyarakat umum bahkan terkadang lintas kota dan negara. Peran yang diperoleh dan dimainkan seorang kyai tidak bisa lepas dari kemampuannya di bidang agama yang diyakini telah memahami ajaran agama dengan baik, sehingga membentuk sebuah otoritas keagamaan. Meminjam istilah Abou Fadl bahwa kemampuan seseorang dalam meyakinkan dan mengarahkan perilaku orang lain dengan sumber otoritatif secara otomatis orang tersebut telah meraih otoritas secara tidak sadar (El Fadl, 2003, p. 37). Dalam persepktif ini, seorang kyai telah memberikan pengaruh kepada masyarakat masalah keagamaan tanpa disadari.

Otoritas yang diperoleh oleh seorang kyai dari masyarkat pada dasarnya bagian dari kepercayaan yang menumbuhkan kharisma dan memantapkan posisi kyai sebagai agent of knowledge (agen pengetahuan) dan agent of social (agen sosial). Pada wilayah ini, seorang kyai telah diyakini oleh masyarakat telah memperoleh kematang spiritual untuk memimpin pesantren dan menjadikan pesantren sebagai pusat peradaban Islam, sehingga pesantren tidak hanya dipandang sebagai tempat yang hanya mendalami ilmu agama semata, karena di pesantren para santri juga diajarkan berbagai hal masalah kehidupan, seperti kemasyarakatan, ilmu batin dan lain sebagainya. Realita tersebut menandakan adanya hubungan kuat antara santri dengan seorang kyai, sehingg tidak mengejutkan ketika pesantren mempunyai relasi yang lebih luas.

Menurut Amir (2011) ada banyak faktor yang menyebabkan luasnya peran dan otorias seorang kyai yaitu, pertama, relasi geneologi, relasi yang didapatkan melalui hubungan biologis-apakah secara langsung atau disebabkan pernikahan-yang dianggap mampu menggantikan dan meneruskan perjuangan seorang ayah. Kedua, relasi ideologi, relasi ini dibangun karena adanya kesamaan tujuan dan sintemen keagamaan maupun golongan. Ketiga, relasi intelektual, yang diikat dengan rasa emosional seorang guru pada muridnya. Keempat, relasi teologis, relasi ini tidak berbeda jauh dengan relasi ideologis, tetapi yang membedakan keduanya ialah sintemen teologi yang tertanama, seperti teologi Asy'ariah yang banyak tersebar di Jawa. Kelima, relasi spiritual, relasi yang dikonstruk dari kesamaan paham tarekat yang diikuti.

Independensi pesantren sebagai pendidikan agama membuka keyakinan masyarakat bahwa pesantren adalah tempat ideal untuk mencari ilmu agama, keyakinan tersebut didukung dengan kharismatik yang dimiliki oleh seorang kyai dalam berperilaku dan ketika menyampaikan ilmu agama. Pada wilayah yang sama, keyakinan tersebut berangkat dari asumsi dasar yaitu berkah. Kalangan santri memaknainya sebagai bertambahnya kabaikan dalam hidup. Makna ini mempunyai ikatan emosional dibandingkan dengan rasional, karena kepatuhan santri pada kyai meliputi pelbagai bidang yang tidak dapat dirasionalkan (Setiawan, 2012). Kepatuhan tersebut tidak hanya berlaku pada seorang kyai, tetapi juga pada istri kyai (nyai). Pada wilayah ini, nyai mempunyai peran signifikan dalam kehidupan di 
pesantren, karena berdasar konsepsi budaya nyai mewakili seorang kyai dalam mengurus santri putri dan pada konteks eksternal ibu nyai terkadang mengurus dan mengisi pengajian di masyarakat umum (Ambarwati \& Husna, 2014).

\section{Agama dan Budaya: Jalan Terjal bagi Kebebasan Perempuan}

Perkembangan ajaran agama pada dasarnya adalah anak dari zamannya karena setiap ajaran agama merupakana wajah dari peradaban yang berkembang di suatu wilayah, seperti al Quran dan Hadis. Kedua sumber agama Islam tersebut tidak bisa dipandang sebagai ajaran murni yang tidak bergelut dengan masanya, atau menilai keduanya hanya bersifat normatif tanpa aspek histori. Anggapan dan penilai tersebut sama halnya menghilangkan sejarah agama dan nilai peradaban manusia. Menurut Amin Abdullah, agama memiliki dua wilayah yang harus diperhatikan yaitu normativitas dan historisitas (Abdullah, 2011). Kedua wilayah ini ibarat dua koin mata uang yang tidak dapat dipisahkan namun bisa dibedakan. Pada wilayah pertama, seseorang dituntut untuk meyakini ajaran agama sebagai pedoman yang tidak dapat dikritisi, karena wilayah ini bagian dari prerogatif Tuhan. Pada wilayah kedua, agama hadir sebagai respon dari problematika masyarakat, sehingga ada jalinan relasional antara ajaran agama dengan kehidupan masyarakat.

Sejarah agama tidak bisa berdiri sendiri, dan bahkan agama juga bersandingan dengan budaya patriarki, seperti beberapa sumber normatif yang menarasikan perempuan berbeda dengan laki-laki. Pada wilayah yang sama, kebijakan atau putusan keagamaan banyak diperankan oleh kaum laki-laki, sehingga secara teologis maupus sosiologis budaya patriarki memiliki pengaruh kuat dalam menarasikan pesan agama. Pada wilayah teologis, ontologi perempuan dinarasikan sebagai makhluk ciptaan nomor dua, yaitu perempuan tercipta dari tulang rusuk kiri laki-laki. Anggapan tersebut tidak secara tegas terdapat dalam al-Qur`an, tetapi berangkat dari hadis Nabi dan mitologi agama-agama dan harus dipahami lebih dalam menilainya (Hasan, 1995).

Berkembangnya mitologi pada wilayah sosial memberikan dampak buruk terhadap kehidupan perempuan, yaitu perempuan dianggap sebagai makhluk terlarang di wilayah publik. Anggapan tersebut adalah bentuk politik patriariki yang diyakini oleh perempuan sebagai takdir yang harus dijalani. Jalinan kuat antara agama dan budaya patriaki telah menemukan formasi ideal untuk mempertahankan dominasi laki-laki, karena mitologi sudah menjadi ajaran yang datang dari Tuhan (Umar, 2001). Dengan bahasa yang mudah ialaha bahwa budaya patriarki berkembang dan berdiri sejajar dengan pemahaman tentang anggapan bahwa laki-laki sebagai kepala keluarga. Menurut Qasim Amin berpendapat, bahwa perempuan kehilangan kebebasannya setelah berkeluarga. Hal itu terjadi di berbagai daerah sebelum Islam datang, yakni Yunani, Roma, Jerman, India, Cina, dan Arab (Amin, 2003).

Perkembangan budaya patriarki berjalan sejajar dengan ajaran agama dan hal ini telah melalui proses panjang dan rentan yang cukup lama. Menurut Inayah proses diskirmian atas perempuan telah melalui proses lama dengan mengeksternalisasi, mengobyektifikasi, dan mereplikasi sehingga dianggap sebagai sebuah kebenaran final (Rohmaniyah, 2014). Begitu juga pandangan patriarki dalam Islam merupakan satu rangkaian dari tradisi sebelumnya. Realitas demikian terus berkembang sampai saat ini di sendi-sendi kehidupan perempaun termasuk kehidupan di dunia pesantren, lebih spesifik di Kauman Kudus. Masyarakat Kauman meyakini bahwa otoritas keagamaan masih didominasi oleh laki-laki. Keyakinan tersebut dikonstruk dari pengajian-pengajian, kebijakan, dan keahlian kaum laki-laki dalam bidang agama, seperti kebijakan tentang seorang perempuan dilarang untuk ziarah kubur dan perempuan dilarang sekolah. Kasus tersebut masih diyakini sebagai ajaran agama yang harus ditaati dan dijalani. Oleh sebab itu, bagi masyarakat Kauman Jekulo tidak sekolah formal adalah hal biasa dan masih terjadi sampai sekarang (hasil wawancara dengan carik desa). Meskipun demikian, usaha-usaha untuk mendekonstruksi pemahaman tersebut masih dan 
terus dilakukan oleh sebagian masyarakat dan keluarga kyai yang lain, namun asumsi tentang kelemahaman perempuan lebih dominan. Hal ini disebabkan kuatnya budaya patriarki dalam bahasa agama.

\section{Memaknai Perjuangan Perempuan di Lingkungan Pesantren Kauman Jekulo Kudus}

Perjuangan perempuan di Indonesia mengalami pasang surut, pergantian masa ikut menyertai perjuangan perempuan di wilayah publik, seperti Kartini yang dikenal tegar dalam memperjuangkan hak-hak perempuan pada penjajahan. Perjuangan tersebut tidak hanya melihat perempuan sebagai individu yang terpisah dari lingkungannya, tetapi Kartini memaknai perempuan sebagai bagian dari peradaban, seperti yang dikutip Mursidah "Kecerdasan pikiran penduduk bumiputera tidak akan maju pesat bila perempuan ketinggalan dalam usaha itu, (yaitu) perempuan jadi pembawa peradaban" (Mursidah, 2012).

Peran Kartini membawa angin segar bagi kehidupan perempuan selanjutnya, meskipun masih banyak tantangan yang harus dihadapi dan diselesaikan terkait dengan posisi dan peran perempuan di wilayah publik. salah satu contoh di daerah Kauman yang masih menganggap perempuan sebagai makhluk ekslusif yang harus dijaga dan di awasi. Salah satu nara sumber yang merupakan salah satu kyai menyampaikan kegelisahan peran perempuan yang hanya dapat dilakukan dalam wilayah privat. Dia menyampaikan:

Aku mbiyen ngerasa'ke pengawasan lan ketertututupan saking garwo kulo selama 25 tahun, kerjane geh teng griyo ngerawat putro (saya dulu meraskan pengawasan dan ketertutupan dari suami selama 25 tahun, kerja di rumah saja merawat anak).

Asumsi ontologis dan psikologi menjadi alasan utama dalam mengawasi perempuan, yaitu secara ontologis perempuan diyakini sebagai bagian dari laki-laki, karena perempuan tercipta dari tulang rusuk laki-laki. Keyakinan tersebut, memberikan peluang bahwa perempuan harus tunduk dan patuh terhadap laki-laki, karena laki-laki adalah orang yang memilikinya secara ontologis. Kepatuhan perempuan terhadap laki-laki tidak hanya bersifat sementara dan keluarga tetapi sampai akhir hayat dan bahkan sampai di akhirat. Selama ini, justifikasi keagamaan masih menjadi dominasi untuk menjadi dasar hukum dan membangun budaya patriarki, sehingga apa yang dialami seorang nyai di atas dengan perilaku ekslusifitas dan tidak memberikan peluang atau peran dengan kemampuan yang dimiliki merupakan bagian dari diskriminasi gender. Fenomena yang dialami oleh seorang nyai di Jekulo Kudus dalam kehidupannya tentang larangan beraktivitas di luar merupakan percontohan dan menjadi satu pemahaman bagi masyarakat sekitar dari segi etika dan keagamaan. Bahwa perempuan dengan pengetahuan yang baik dan kecapakan agama tidak menjadi jaminan untuk selamat dari budaya patriarki.

Menurut Dwi Ratna (2016) salah satu problematika yang muncul di permukaan pesantren termasuk di Kauman Jekulo Kudus terkait dengan ketidakadilan gender ialah karena kajian yang dilakukan berdasarkan penjelasan kitab kuning yang telah mengarah pada budaya patriarki. Pada wilayah yang berbeda, munculnya patriarki berawal dari kuatnya dominasi laki-laki dalam memberikan komentar dan penafsiran pada al Quran, sehingga hampir kitab tafsir yang dikenal dan diajarkan diproduksi oleh laki-laki (Rohmaniyah, 2014). Realita demikian menimbulkan satu asumsi bahwa kekuasaan laki-laki terhadap perempuan bersifat kekal dan abadi dan hal ini tidak dapat dikritisi karena berangkat dari sumber otoritatif agama yang diyakini kebenarannya. Menurutu Muhtador dalam penelitiannya, bahwa kebebasan perempuan ditentukan oleh laki-laki. Kuatnya kuasa laki-laki terhadap perempuan tidak hanya bersifat kekeluargaan, tetapi terkadang melampaui batas kekuatannya, seperti perempuan harus mematuhi pilihan bapaknya dalam berjodoh (Muhtador, 2015).

Dalam peribahasa dikenal dengan "setali tiga uang" yaitu bahwa adanya masyarakat yang tidak melanjutkan pada pendidikan formal yang lebih tinggi karena kepatuhan penuh atas takdir perjodohan yang ditentukan oleh orang tua laki-laki, seperti yang dialami keluarga 
dari penjual kelontong di Jekulo Kudus yang suaminya masih mempunyai hubungan darah dengan keluarga dengan kyai mengungkapkan bahwa tidak pentingnya melanjutkan pendidikan formal sampai jenjang tinggi, cukup SD dan bisa membaca, pada akhirnya akan menikah dan taat pada suami. Femonena ini tidak hanya dilakukan sendiri oleh keluarga tersebut, tetapi hampir mayoritas satu gang di wilayah Jekulo ini mengaplikasikan putus sekolah. Realitas ini menunjukkan kesamaan antara orang yang berpendidikan tinggi dan tidak harus memenuhi tuntutan dan taat kepada orang tuan atau suami yang telah dipilihkan. Menurut Anwar (2016) kesenjangan hubungan dan hilangnya pendidikan dalam keluarga yang bersifat relasi gender memunculkan problematika. Oleh sebab itu, petingnya pendidikan keluarga yang responsif gender untuk membangun harmoni melalui sumber daya keluarga.

Ketaatan dan diskriminasi gender dalam memilih pasangan dan kebeban untuk berpendidikan yang digambarkan satu gang di lingkungan pesantren tersebut bentuk penentangan yang disikapi dengan diam, sehingga dianggap telah menyetujui pilihannya orang tua dalam sistem kehidupan rumah tangga. Begitu juga ketika telah berumah tangga, banyak sumber-sumber otoritatif yang menyebutkan bahwa seorang perempuan yang meninggal dan suaminya tidak ikhlas, perempuan tersebut akan masuk neraka. Argumentasi tersebut bersebaran dan juga digunakan dalam ruang patriarki sebagai alat justifikasi bagi perempuan yang berani mengingkari kekuasaan laki-laki.

Secara psikologis, perempuan dianggap sebagai makhluk lemah akal dan agamanya. Kelemahaman perempuan secara akal disebabkan faktor persaksian perempuan yang tidak seimbang dengan laki-laki, yaitu dua lawan satu. Begitu juga perempuan dianggap lemah agamanya karena dalam satu bulan perempuan tidak penuh melaksankan ajaran agama disebabkan haid (Amin, 2003). Kelemahan perempuan dari aspek akal dan agama dalam bahasa agama telah menjerumuskan nasib perempuan pada kegagalan membangun lingkungan yang responsif gender, seperti dilarangnya perempuan shalat di masjid di sekitar pondok Kauman Jekulo Kudus, perempuan tidak boleh mengikuti pengajian haul dan perempuan tidak boleh berpendidikan tinggi dan cukup sekolah dasar. Fenomena demikian diaplikasikan di salah satu pondok di sekitar yang melarang santri untuk mondok ketika melanjutkan pada jenjang tsanawiyah atau SMP, sehingga santri yang ingin mondok harus melepas sekolah sederajat.

Realitas tersebut pada satu sisi mengambaikan ajaran perintah agama di mana perempuan sebagai madrasah al ula telah diputus oleh sistem patriarki yang membatasi pendidikan perempuan. Menurut Siti Mahmudah Noorhayati (2017) pada dasarnya, nyai mempunyai peran strategis dalam mengatur dan memperdayaan santri dan masyarakat perempuan dalam mengembangkan wacana gender yang dipahami, supaya perempuan dapat terlibat dalam kehidupan sosial. Oleh sebab itu, dibutuhkan perempuan yang hebat dan mempunyai kompetensi dalam melihat tantangan dan peran seperti para Bu Nyai di Pondok Pesantren Nurul Jadid Paiton.

Celakanya, asumsi tentang ketaatan sudah diyakini sebagai ajaran agama karena sudah tercatat dan menjadi narasi dari bahasa agama yang membudaya. Kuatnya relasi agama dan budaya juga terasa di wilayah pesantren. Pesantren yang menjadi pusat kajian keagamaan juga berkontribusi atas kuatnya paham patriarki di masyarakat, seperti di Jekulo yang melarang perempuan beraktivitas di luar rumah. Namun tidak berarti perempuan tidak dapat berkontribusi pada masyarkatnya, karena secara fungsional perempuan mempunyai otoritas keagamaan seperti halnya para laki-laki.

Hadirnya perempuan di wilayah publik tidak dalam rangka merebut dominasi laki-laki atau kritik atas otoritas keagamaan laki-laki. Hadirnya perempuan di ruang publik mempunyai banyak argumentasi, termasuk ialah memberikan pemahaman bahwa hanya perempuan yang memahami dan mengerti persoalan wanita. Bagi laki-laki perempuan hanya sebuah teori dalam memahaminya karena laki-laki tidak pernah melakukan haid, melahirkan, 
menyusui dan semua yang menjadi kodrat bagi perempuan. Oleh sebab itu hadirnya perempuan di ruang publik menjadi penting sebagai solusi dari problem keagamaan yang mengitari. Di Jekulo Kudus, perempuan tidak hanya menjadi nyai yang melayani kyai dan putra-putrinya dalam kehidupan sehari-hari, karena perempuan di Kauman mempunyai peran aktif dalam membentuk kehidupan. Langkah ini diambil dengan resiko yang besar, karena harus melewati proses dari perjalanan panjang dan hadangan budaya patriarki.

Perjuangan perempuan di daerah Kauman tidak hanya sebatas pada ruang privat pesantren, tetapi juga meluas pada wilayah publik, seperti menjadi pengurus pengajian mingguan, menjadi pengurus organisasi thariqah/tarekat, pendidik, politisi. Kegigihan perempuan di wilayah Jekulo ini dalam memperjuangkan entitas dan eksitensisnya menumbuhkan otoritas keagamaan seperti yang diperoleh para laki-laki. Otoritas tersebut yang mendukung peran perempuan di ruang publik untuk menyampaikan pesan-pesan keagamaan, sehingga perempuan tidak hanya menjadi objek tetapi juga menjadi subjek dalam menyampaikan pesan-pesan agama.

Kemunculan perempuan di wilayah publik memberikan sinyal bahwa perempuan tidak lagi memaknai agama dan budaya sebagai penjara. Menurut Shiva (1997) bahwa pemahaman tersebut mengindikasikan bahwa keperempuan mampu konstruksi epistemologinya sendiri yang disebut dengan women's way of knowing yaitu memproduksi pengetahuan tentang perempuan yang berbasisi pada prinsip feminimisme. Dengan kata lain, perempuan sudah menemukan identitas dirinya dalam berproses untuk perubahan entitasnya.

Perubahan entitas dan identitas perempuan juga terjadi di sekitar Kauman Jekulo Kudus. Perubahan tersebut mempengaruhi otorias perempuan yang awalnya dianggap sebagai makhluk ekslusif, tetapi massifnya peran yang dimainakan tokoh perempuan di wilayah publik di sekitar pesantren mengubah pandangan pada perempuan. Adapun otoritas yang dimainkan perempuan dalam mengkonstruksi pesan-pesan agama terbagi pada dua bagian, dengan meminjam teori otoritas Abou Fadl (2001, p. 37) yaitu otoritas koersif dan otoritas persuasif.

Otoritas pertama lebih menekankan pada wilayah struktural, yaitu kemampuan untuk mengarahkan perilaku orang lain dengan cara membujuk, mengambil keuntungan, mengancam, atau menghukum. Otoritas demikian dimainkan dari golongan perempuan yang mempunyai pendidikan tinggi, karena mempunyai posisi strategis, seperti guru, struktur desa, DPR dan aktivis perempuan. Peran yang dimainkan lebih pada pesan legal-formal yang bersifat keagamaan dalam ranah struktural kenegaraan, seperti contoh istri pak RT yang menjadi Kepala Sekolah SD di Jekulo Kudus. Secara struktural peran yang dimainkannya lebih bersifat strategis dalam kebijakan sekolah yang responsif gender.

Dalam kontek otoritas, perempuan dapat memainkan peran sebagai kepala sekolah untuk mengembangkan atau menghadirkan wacana gender dalam konteks pendidikan keagamaan yang harus dipatuhi oleh guru laki-laki maupun permepuan. Hadirnya perempuan sebagai pemegang kebijak secara professional dapat dikatakan sebagai ulama karena telah mememperjuangkan pendidikan yang berkeadilan gender untuk meretas ketidakadilan gender (Umma Farida \& Kasdi, 2018; Isnaini, 2016). Begitu juga diungkapkan oleh Takdir (2015) yang menggambarkan peran perempuan di Madura bahwa nyai As'ad dapat disebut ulama, karena mempunyai kompetensi dan kepedulian untuk membangun moral dan etika yang berbasis gender.

Pada wilayah berbeda, beberapa nyai menjadi pengurus Jatman (Jam'iyyah Ahlith Thariqah Al Mu'tabarah An Nahdliyyah) juga memainkan perannya dalam konteks struktural yaitu dengan menjadi pengurus cabang thariqat Jatman Kudus. Posisi ini secara tegas menolak anggapan dan asumsi yang berkambang bahwa perempuan kurang secara akal dan agama. Meskipun wilayah wewenang hanya terbatas pada perempuan, tetapi secara fungsional ini menjadi gambaran dan peran perempuan dalam ranah publik. Dengan demikian, aturan yang 
disepakati bersama yang diproduksi oleh perempuan harus dipatuhi, seperti peraturan tentang perempuan yang wajib hadir pada waktu acara organisasi Thariqah Naqsabandiyah Khalidiyah. Dalam tuturannya, seorang aktivis thariqah perempuan berucap bahwa organisasi memerintahkan kewajiban anggota hadir dalam perkumpulan 3 bulan sekali atau 6 bulan sekali. Otoritas ini mempunyai hubungan struktural dan mempunyai kekuatan kuat dalam organisasi.

Pada wilayah kedua terdapat otoritas persuasif yaitu otoritas yang melibatkan kekuasaan yang bersifat normatif yang kemampuan mengarahkan keyakinan atau perilaku seseorang atas dasar kepercayaan. Dalam hal ini, keahlian mempunyai andil dalam mempengaruhi atau mengarahkan perilaku individu. Menurut Weber yang dikutip oleh Anding Kusdiana (2014), kemampuan tersebut bisa berangkat dari otoritas kharismatis dan otoritas tradisional. Melihat karakter pembagian otoritas tersebut tidak ada perbedaan dengan otoritas persuasif, tetapi otoritas persuasif lebih dahulu, sebelum otoritas kharisma. Adapun anggota atau kelompok yang memiliki otoritas persuasif ialah dari golongan nyai atau perempuan tradisional, tetapi yang urgen dalam hal ini ialah, bahwa perempuan di Kauman Jekulo Kudus dapat melibatkan kemampuannya ketika mengajarkan tentang ajaran agama, sehingga seorang audien terpengaruh dan harus memilih mematuhi setiap fatwa yang dikeluarkan, seperti ketika seorang nyai menyampaikan pesan-pesan ibadah, kematian, dan ajaran al Quran. Audien secara tidak sadar sudah mematuhi.

Fatwa-fatwa demikian banyak dikeluarkan atau diucapkan ketika para wali santri mengantarkan anaknya mondok atau dalam rangka silaturahmi ke pesantren ini. Dalam kontek pendidikan pesantren, budaya atau tradisi mengantarkan anak mondok atau hanya sebatas silaturahmi sangat kuat, karena mempererat hubungan secara batin. Kepuasan ini menjadi momentum menguatnya posisi Bu Nyai atau perempuan dalam aspek keagamaan, sehingga fatwa yang diucapkan menjadi keyakinan dari ajaran agama. Menurut Ambarwati dan Husna (2014) tradisi demikian merupakan ciri khas dalam dunia pesantren, di mana istri kyai (nyai) dapat menjadi superior dan menggantikan peran kyai dalam menyambut atau menemui tamu istri yang sedang datang ke rumahnya.

Dengan demikian, otorias yang mengitari para perempuan mempunyai objek sendiri, yaitu status sosial dan pendidikan dapat mempengaruhi pada objek yang diayomi, seperti peran koersif lebih banyak pada wilayah sosial yang cakupannya lebih luas. Hal ini berbeda dengan otoritas persuasif yang hanya melingkupi kalangan RT dan atau pada orang tua santri atau alumni. Pengaruh tersebut tidak menjadi beban dalam memain otoritas keagamaan perempuaan, karena masing-masing klasifikasi telah memainkan perannya sebagai perempuan yang mandiri dan memaknai eksistensinya, dan ajaran agama tidak hanya di dominasi oleh kelompok laki-laki..

\section{KESIMPULAN}

Gagasan tentang perempuan di atas menggambarkan bahwa perempuan tidak bisa dianggap sebagai makhluk ekslusif, karena perempuan bisa mempunyai peran sebagaimana laki-laki dalam mengajarkan agama kepada komunitasnya dan peran keagamaan ini sangat strategis dalam membangun peradaban bagi kaum perempuan.

Eksistensi perempuan yang hadir dalam wilayah publik tidak lagi mempunyai sterotip negative yang dianggap sebagai bencana bagi masyarakat, pasalnya ada banyak perempuan di Desa Kauman Jekulo yang berkontribusi dalam dunia pendidikan dan sosial-keagamaan, seperti menjadi kepala sekola di SDN dan menjadi pengurus di organisasi keagamaan Jatman. Posisi ini memberikan gambaran positif, karena mengajarkan warga dan masyarakat atas posisi perempuan, peran demikian biasa disebut dengan otoritas koersif yang berkontribus secara struktural atau legal-foormal yang dapat mempengaruhi masyarat atau audien dengan jabatan yang diembannya. 
Demikian pula dengan posisi perempuan yang memainkan peran dalam konteks sosialkultural, yaitu perempuan yang menjadi Bu Nyai dan menggantikan kyai dalam wilayah rumah tangga. Dengan bahasa sederhana, istri menerima tamu perempuan yang silaturahmi dan memondokkan anaknya. Peran ini sangat bendorong bagi seorang istri atau nyai memberikan fatwa keagamaan dalam wilayah perempuan dan biasa disebut dengan otoritas persuasif. Otoritas ini yang mempunyai hubungan norma dalam mempengaurhi orang lain.

\section{REFERENSI}

Abdullah, A. (2011). Studi Agama; Normativitas atau Historisitas (Cet. V, Ed.). Pustaka Pelajar.

Ambarwati, \& Husna, A. (2014). Manajemen Pesantren Responsif Gender: Studi Analisis di Kepemimpinan Nyai Pesantren di Kabupaten Pati. Jurnal Palastren, 7(2), 457-482.

Amin, Q. (2003). Sejarah Penindasan Perempuan,. IRCiSoD.

Anwar, S. (2016). Urgensi Pendidikan Gender dalam Keluarga. Terampil, 3(2). https://doi.org/10.24042/terampil.v3i2.1181

Aviv. (2015). Pesantren-Pesantren di Bareng Jekulo Kudus. Santripedia. https://santripedia.wordpress.com/2015/04/05/pesantren-pesantren-di-bareng-jekulokudus/

El Fadl, K. A. (2001). Melawan Tentara Tuhan. Serambi.

El Fadl, K. A. (2003). Atas Nama Tuhan. Serambi.

Fadhilah, A. (2011). Struktur dan Pola Kepemimpinan Kyai dalam Pesantren Jawa. Hunafa: Jurnal Studia Islamika, 8(1).

Farida, Ulyani. (2014). Politik kePemimPinan Pesantren: Peran Publik Perempuan di Pesantren Daarut tauhiid Bandung. Palastren, $7(2)$. http://dx.doi.org/10.21043/palastren.v7i2.1033

Farida, Umma, \& Kasdi, A. (2018). The 2017 KUPI Congeress and Indonesian Female 'Ulama .' Journal of Indonesian Islam, 12(2). https://doi.org/10.15642/JIIS.2018.12.2.135-158

Hajar, Ibnu. (2009). Kyai di Tengah Pusaran Politik. IRCiSoD.

Hasan, R. (1995). Isu Kesetaraan Laki-laki Perempuan dalam Tradisi Islam. In Setara di Hadapan Tuhan. Yayasan Prakarsa.

Hasbullah. (1999). Sejarah Pendidikan Islam di Indonesia: Lintasan Sejarah Pertumbuhan dan Perkembangan. Raja Grafindo Persada.

Isnaini, R. L. (2016). Ulama Perempuan dan Dedikasinya dalam Pendidikan Islam (Telaah Pemikiran Rahmah El-Yunusiyah). Jurnal Pendidikan Islam, 4(1). https://doi.org/10.15642/jpai.2016.4.1.1-19

Kusdiana, A. (2014). Sejarah Pesantren: Jejak, Penyebaran, dan Jaringan di Wilayah Priangin. Bandung.

Marhumah. (2012). Konstruksi Gender, Hegemoni Kekuasaan, dan Lembaga Pendidikan. Karsa, 19(2). http://dx.doi.org/10.19105/karsa.v19i2.64 
Mernisi, F., \& Hasan, R. (1991). Makna misoginis berhubungan dengan persepsi kebencian atas perempuan, dan kajian hadis misoginis. In Wanita di dalam Islam, terj. Yaziar Radianti (Bandung: Pustaka, 1991), hlm. 62-104. Pustaka.

Moleong, L. J. (2002). Metodologi Penelitian Kualitatif. Remaja Rosdakarya.

Muafiah, E. A. . (2013). Pendidikan Perempuan di Pondok Pesantren. Jurnal Nadwa; Pendidikan Islam, 7(1).

Muhsin, A. W. (1994). Wanita di dalam al Qur'an. Mizan.

Muhtador, M. (2015). Hadis-hadis misoginis dalam perspektif gender dan hermeneutika (studi hadis tentang perempuan dalam keluarga). Universitas Islam Negeri Sunan Kalijaga.

Muhtador, M. (2017). Analisis Gender: Membaca Perempuan Dalam Hadis Misoginis ( Usaha Kontekstualisasi Nilai Kemanusiaan ). Jurnal Buana Gender, 2(1). https://doi.org/10.22515/bg.v2i1.783

Mursidah. (2012). Gerakan Organisasi Perempuan Indonesia. Jurnal MUWÂZÂH, 4(1), 87103.

Noorhayati, S. M. (2017). Pemikiran Islam terhadap Gender dan Pemberdayaan Perempuan (Studi Pemikiran dan Model Pemberdayaan Nyai di Pondok Pesantren Nurul Jadid Paiton ). Akademika: Jurnal Pemikiran Islam, 22(2). https://doi.org/10.32332/akademika.v22i2.953

Ratnasari, D. (2016). Pemberdayaan Perempuan dalam Pendidikan Pesantren. Pesantren Dan Pendidikan Islam Indonesia, 9(1).

Rohmaniyah, I. (2014). Konstruksi Patriarki dalam Tafsir Agama Sebuah Jalan Panjang. Fakultas Ushuluddin dan Pemikiran Islam kerjasama Pustaka Indonesia.

Setiawan, E. (2012). EKSISTENSI BUDAYA PATRON KLIEN DALAM PESANTREN : Studi Hubungan Antara Kyai dan Santri. 13(2), 137-152.

Shiva, V. (1997). Bebas dari Pembangunan Perempuan Ekologi dan Perjuangan Hidup di India, (Penerjemah). Obor Indonesia.

Takdir, M. (2015). Kiprah Ulama Perempuan Nyai Hj. Makkiyah As'ad dalam Membentengi Moralitas Umat di Pamekasan Madura. Jurnal Kebudayaan Dan Ilmu Keislaman, 8(1).

Ulya. (2010). Metode Penelitian Tafsir. Nora Media Enterprise.

Umar, N. (2001). Argumen Kesetaraan Gender Perspektif Al-Qur'an (I). Paramadina.

Vita, A. (2014). Hegemoni Kyai terhadap Praktik Poligami. Musawa: Jurnal Studi Gender Dan Islam, 13(2). https://doi.org/10.14421/musawa.2014.132.127-140 
50 | Volume 10, No. 1, Januari-Juni 2020

() 2020 by Kafa'ah All right reserved. This work is licensed under (CC-BY-SA) 